\title{
バドミントンシャトルコックの空カ安定性
}

\author{
中川 健一 ${ }^{* 1}$, 長谷川 裕晃 ${ }^{* 2}$, 村上 正秀*3, 大林 茂*4
}

\section{Aerodynamic stability of a badminton shuttlecock}

\author{
Kenichi NAKAGAWA*1 ${ }^{*}$, Hiroaki HASEGAWA*2 ${ }^{*}$, Masahide MURAKAMI*3 \\ and Shigeru OBAYASHI ${ }^{* 4}$ \\ ${ }^{* 1}$ Department of Mechanical System Engineering, Utsunomiya University \\ 7-1-2 Yoto, Utsunomiya-shi, Tochigi 321-8585, Japan \\ ${ }^{* 2}$ The Graduate School of Engineering, Utsunomiya University \\ 7-1-2 Yoto, Utsunomiya-shi, Tochigi 321-8585, Japan \\ ${ }^{* 3}$ University of Tsukuba \\ 1-1-1 Tennoudai, Tsukuba-shi, Ibaraki 305-8577, Japan \\ ${ }^{* 4}$ Institute of Fluid Science, Tohoku University \\ 2-1-1 Katahira, Aoba-ku, Sendai-shi, Miyagi 980-8577, Japan
}

Received: 12 April 2017; Revised: 27 September 2017; Accepted: 20 November 2017

\begin{abstract}
Badminton is one of the most popular sports in the world and is famous as the sport having the fastest initial velocity of a batted ball among all ball games. Initial velocity immediately after smashing may reach up to $408 \mathrm{~km} / \mathrm{h}(113 \mathrm{~m} / \mathrm{s})$ at maximum. A badminton shuttlecock generates significant aerodynamic drag and it was confirmed that the high deceleration characteristics was related to the slots located at the leg portion of a shuttlecock in the previous study. Turnover refers to the flipping experienced by a shuttlecock when undergoing heading change from nose pointing against the flight path at the moment of impact and a shuttlecock indicates the aerodynamically stable feature for the flip movement just after impact. The purpose of this study is to investigate the effect of gaps on the aerodynamic stability (turnover stability) of a badminton shuttlecock during the flip phenomenon. In the present study, the flow field around the shuttlecock during impulsive change of an angle of attack (flip movement) was measured by using the smoke flow visualization and the behavior of the shuttlecock during the flip movement was evaluated in comparison with that of the conic model (with no gaps). The turnover stability of a badminton shuttlecock is affected by gaps of the shuttlecock skirt.
\end{abstract}

Keywords : Aerodynamic stability, Badominton shuttlecock, Flipping motion, Flow visualization, Fluid forces, Pitcing moment, Vortex

\section{1. 緒言}

バドミントンは，近年ロンドン五輪で日本史上初のメダルを獲得し，またリオ五輪では金メダルを獲得するな ど，日本中が沸き競技の注目度が増すとともに，手軽にできるレジャースポーツとしての魅力も改めて注目され るようになってきた. バドミントンは全ての球技の中で打球の初速が最も速いことが知られている. スマッシュ 直後の初速は，最速で時速 $408 \mathrm{~km}(113 \mathrm{~m} / \mathrm{s})$ に達することもある(BADMINTON NEWS, 2017). バドミントンが 他の競技と大きく異なる点として，使用する球がシャトル状の独特な形状を有している点が挙げられる.シャト

No.17-00165 [DOI:10.1299/transjsme.17-00165], J-STAGE Advance Publication date : 30 November, 2017

*1 正員, 宇都宮大学工学部（干321-8585 杤木県宇都宮市陽東 7-1-2）

*2 正員, 宇都宮大学大学院 工学研究科

*3 筑波大学（干305-8577 茨城県つくば市天王台 1-1-1）

*4 正員, フェロー, 東北大学流体科学研究所（广980-8577 宮城県仙台市青葉区片平 2-1-1）

E-mail of corresponding author: k_nkgw@cc.utsunomiya-u.ac.jp 
ルコック（シャトル）は球形状ではなく, 略円錐台形状をしており，半球形状のコルクに，水鳥等の羽根を接着 剤などで固定した簡単なつくりになっている. バドミントンはコースとスピードの緩急で試合をするスポーツと して知られ，緩急を使い分ける様々なショットやフットワーク，対戦相手との駆け引きを要する．このシャトル のスピードは，力の入れ具合でも変化させることができるため，バドミントンでは簡単に戦略性の高いゲームが 楽しめる.こうしたバドミントンの魅力を引き出している要因に，シャトルの有する飛翔体としての空力特性が あげられる. シャトルは非常に抵抗の大きい飛翔体で, 相手コートに届くまでに空気抵抗を受けて急激に減速す る.たとえば，初速 $67 \mathrm{~m} / \mathrm{s}$ で打ち出した場合，約 0.6 秒後には $7 \mathrm{~m} / \mathrm{s}$ まで急速に減速する(Cooke, 2002). こうし たシャトルの初速と終速の差が著しいことも，他の球技には無い大きな特徴と言える.

これまでのシャトルに関する研究では, さまざまなショットによる軌道の実験的解析および数值シミュレーシ ヨンやショット時の動作解析についての研究など, 道具やバイオメカニクス的視点についての研究は盛んに行わ れてきた(湯他, 1994).さらに, シャトルの空力特性に関して, シャトル周りや後方での流れ場についての可視 化(Cooke, 1999)をはじめ, 数種類の形状のシャトルを使用した結果が報告されている(Alam et al., 2010) (Alam et al.,2009). 加えて我々の過去の研究より, シャトルの独特な形状に高い減速特性が由来していることが明らかに なっている(長谷川他, 2013).

シャトルの構成はコルク部, スカート状に隣同士の羽根が織り重なり合うように配置された羽根部, そしてス カート付け根の隙間部の三つの構成要素からなる. 飛翔中のシャトルは通常，スピン回転する. その回転方向は 進行方向に対してシャトルの羽根側（シャトルの飛翔方向からみて後ろ側）から見て, 反時計回りである. 一般 にスピン回転する飛翔体と言えば，弓矢などが挙げられ，矢羽によりスピン回転が生まれジャイロ効果により飛 翔軌道が安定している事は広く知られている. 大川らは, 鏃や矢羽形状および矢の細長比に着目し, 細長比が飛 翔安定性に大きく寄与していることを明らかにし（大川他，2013）, 次いで矢羽形状の違いによりスピン回転数と 姿勢安定効果について言及している(鈴木他，2010). 一方，シャトルはスピン回転による姿勢安定性とは別に， インパクト直後にクルリと反転し急激に迎角変化（縦回転）し, 非常に短い時間で安定した飛翔を行う. そこで, 本研究ではこのインパクト直後の飛翔安定性に焦点をあてる. 実際のシャトルでは, この縦回転時の姿勢変化中 にはスピン回転していない. シャトルの有するユニークな挙動および空力安定性おいて, Lin らはラケットでイ ンパクト時のシャトルの変形と姿勢安定性に関して, 数種類のシャトルを使用して調べており (Lin el al., 2013), Cohen らはインパクト後のシャトル挙動（宙返り挙動）を詳細に調ベシャトル形状の違いが及ぼす影響について も報告している(Cohen et al., 2015). しかし空力安定性について, シャトル周りの流れ場からの議論が十分になさ れているとは言い難い. そこで, 本論文ではシャトルの急激な姿勢変化を伴う空力特性に着目し, 風洞実験によ り流体力と流れ場の評価を実施した. 特に, シャトルの安定性と縦回転時の挙動における隙間部の影響について, 隙間のない円錐台型のシャトルとの比較により調べた.

\section{2. 実験装置および方法}

本実験で使用する実験装置の概略図を図 1 に示す. 実験には東北大学流体科学研究所の小型低乱風洞を用いた. 風洞は $0.29 \times 0.29 \mathrm{~m}$ の正八角形の吹き出し口を有する回流風洞である. 測定部は開放型で, 主流速は $5 \sim 55 \mathrm{~m} / \mathrm{s}$ の 範囲で調整可能である. シャトルを設置する測定部中心での乱れ強さは $0.4 \%$ 以下である(小浜他, 1982). 座標系 は主流方向を $X$, 測定部間口方向を $Y$, 高さ方向を $Z$, とし, シャトル重心を原点とした. 図 1 のシャトルの状態 が迎角 $0^{\circ} ， Z$ 軸まわりに時計回転方向を正とする．ピッチングモーメントの正方向は，Z軸周りに時計回転であ る. 図 2 に実験に用いたシャトルを示す。用いた供試体には, 試合球として利用されている第一種検定合格球,

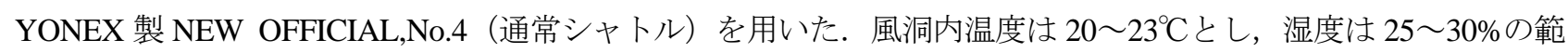
囲で実験を行った。シャトルの外観は，可視化実験の際に生じるシャトルのハレーションを抑えるために表面を 黒色に塗装した．図 2(b)の Conic w/o gaps（隙間無し円錐シャトル）は隙間部を通る流れが飛翔に及ぼす影響を調 べる為に，隙間部を塞いだものである．このシャトルは，スカート部の羽を取り除き，シャトル全体に和紙を貼 り付けて円錐形状となるようにした. 用いた和紙は通気性のない薄くて軽量なものとした，そのため，オリジナ ルシャトルに比べて顕著な重量増は抑えられ，慣性モーメントの違いによる影響は排除されている．用いたシャ トル 


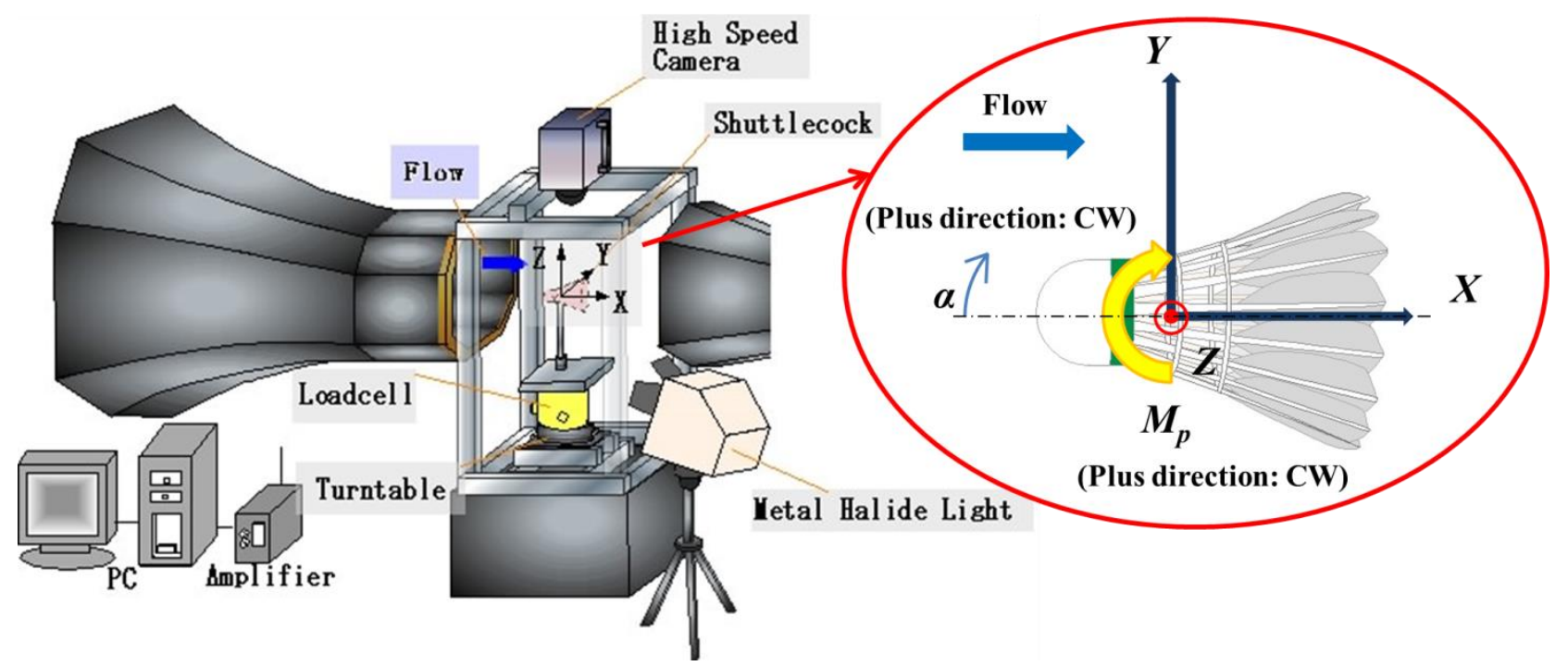

Fig. 1 An overview of the wind tunnel experimental setup is shown in Fig.1. The wind tunnel experiment was carried out using a low-turbulence wind tunnel at Tohoku University, Japan. The test section was octagonal, $0.29 \mathrm{~m}$ in width and $0.29 \mathrm{~m}$ in height, and experiments were performed in the middle of the open part of the test section. The origins of coordinates $X, Y$, and $Z$ were defined as the center of mass of a shuttlecock.

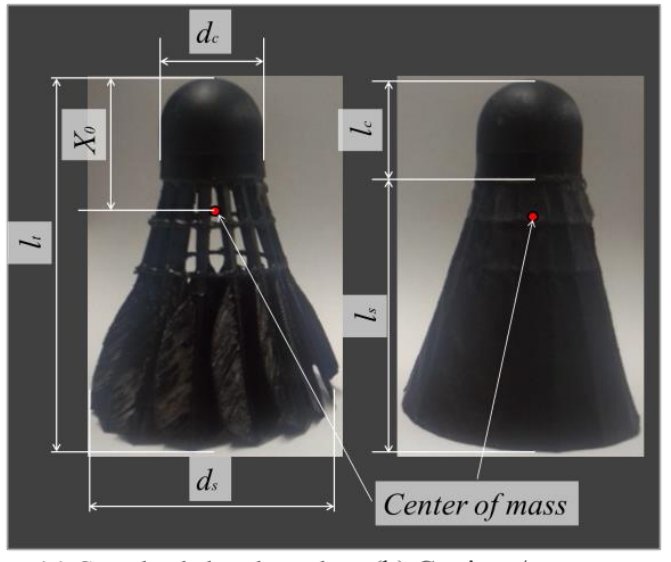

(a) Standard shuttlecock

(b) Conic w/o gaps

Fig. 2 The model tests were conducted using full-size models of shuttlecocks. A standard shuttlecock is shown in (a). The shuttlecock prototype (conic without gaps) has been Table 1 The dimensions of shuttlecock models were given in Table 1. The shuttlecocks selected for this research were manufactured by YONEX Co. YONEX feather shuttlecocks, which are the official choice for the world's leading international tournaments, are manufactured to ensure the correct speed, distance, and stability performance under different temperatures and environments.

\begin{tabular}{l|l|c|c}
\hline \hline Shuttle type & & Standard & Conic w/o gaps \\
\hline The total length [mm] & $l$ & 85.0 & 85.0 \\
\hline Length of shuttle skirt [mm] & $l_{s}$ & 60.0 & 60.0 \\
\hline Length of cork [mm] & $l_{c}$ & 25.0 & 25.0 \\
\hline Diameter of skirt [mm] & $d_{s}$ & 66.0 & 66.0 \\
\hline Diameter of cork [mm] & $d_{c}$ & 26.4 & 26.4 \\
\hline Mass [g] & $m$ & 6.0 & 6.6 \\
\hline Distance of center of mass [mm] & $l_{0}$ & 29.9 & 32.7 \\
\hline
\end{tabular}
through the gaps in the shuttlecock skirt on aerodynamic stability. A conic without gaps shown in (b) was completely covered with a smoothed light paper with no porosity.

の主要寸法を表 1 に示す。 レイノルズ数 Re は，シャトル最大幅である羽根部後端径 $d_{s}$ を代表長さ，主流速 $U_{0}$ を代表速度， $v$ を動粘性係数として，Re= $U_{0} d s / v$ と定義した. シャトルに作用する流体力については，三分力天科 (LMC-3501-50N, NISSHO ELECTRIC WORKS）および，ひずみアンプ(DSA-100A, NISSHO ELECTRIC WORKS) を用い，揚力 $L$, 抗力 $D$, ピッチングモーメント $M_{p}$ を測定した. 流体力測定は $R e=4.4 \times 10^{4} \sim 1.3 \times 10^{5} \quad\left(U_{0}=10 \sim\right.$ $30 \mathrm{~m} / \mathrm{s}$ ) の範囲で実施した. シャトル回りの流れ場の可視化は Smoke-Wire 法を用いて行った. ワイヤーは $0.05 \mathrm{~mm}$ のニクロム線を用い，流動パラフィンを塗布して実施した． ワイヤーの配置位置は $X / d_{s}=-2.3, Y / d_{s}=0.0$ である. 可 視化にはハイスピードカメラ(FASTCAM SAX2, FASTCAM MC2, Photron Ltd), メタルハライドライト(HVC-SL, Photron Ltd)を用いた. 可視化実験は $R e=4.4 \times 10^{4} \sim 1.3 \times 10^{5}$ の範囲で実施した。 また，本実験で使用したシャトル 


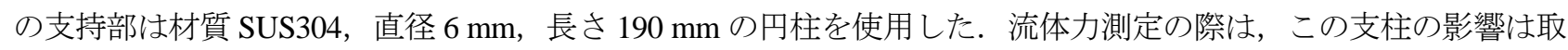
り除き，縦回転挙動時に支柱から発生する流れがシャトルと干渉していないことを事前に確認した.

\section{3. 実験結果および考察}

\section{$3 \cdot 1$ シャトルに作用する空力特性}

図 3 に各迎角における定常流体力特性を示す，主流速を変化させた際の流体力については，通常シャトルおよ び隙間無し円錐シャトル，いずれの場合でも傾向は類似していた．迎角 $\alpha$ は20刻みで測定を行った. シャトルは 軸対称物体であるので, 以下に示寸迎角を変化させた場合の流体力変動については, 正の迎角の範囲で説明する.

図 3(a)に揚力係数曲線を示す，迎角が大きくなると，通常シャトルと隙間無し円錐シャトルでの差は顕著にな る. 迎角が $110^{\circ}$ 超えたあたりから隙間無し円錐シャトルでは揚力が急に増加する．迎角が $90^{\circ}$ 超えると，シ ヤトルスカート端は上流側を向き始める. 通常シャトルの場合, 隙間部を有する為に, スカート端からシャトル 内部一流れが入り込み，隙間部を通って流れ出る，一方，隙間無し円錐シャトルでは隙間がないため，シャトル 内部を通過する流れは発生しない. 内部に入り込んだ流れは, シャトルスカート部上側の内側に沿って流れる. この流れがシャトルを押寸力となり, シャトルが傾いていることで上向きの力を生み, 揚力が増加する. シャト ルスカート部の開角は約 $20^{\circ}$ である. そのため, シャトル下側のスカート部が主流と水平になる迎角 $160^{\circ}$ 超え ると，このシャトルを上方に押す力が小さくなるため揚力は減少していく．その後，迎角 $180^{\circ}$ でシャトルが完全 に下流側を向くと揚力はゼロとなる.

図 3(b)に抗力係数曲線を示寸. 迎角が 0 ○の場合, 通常シャトルは隙間無し円錐シャトルよりも， $C_{D}$ は約 3 割大

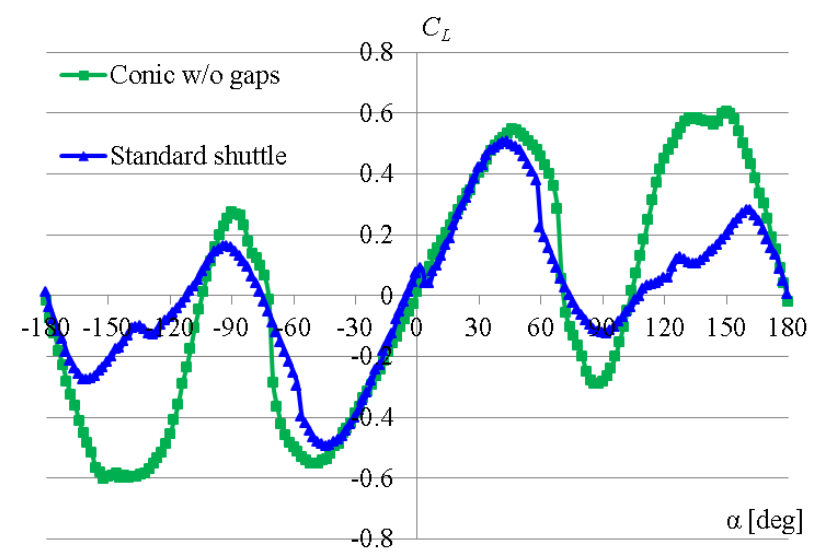

(a) Lift coefficients

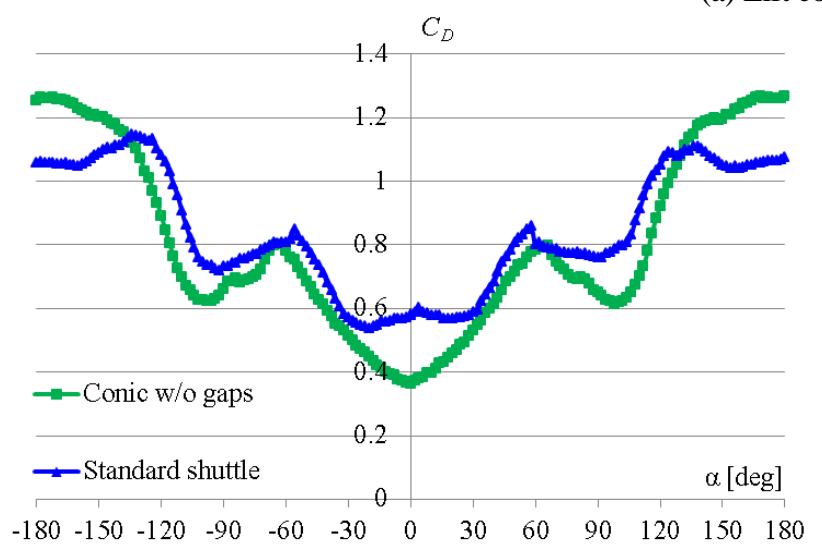

(b) Drag coefficients

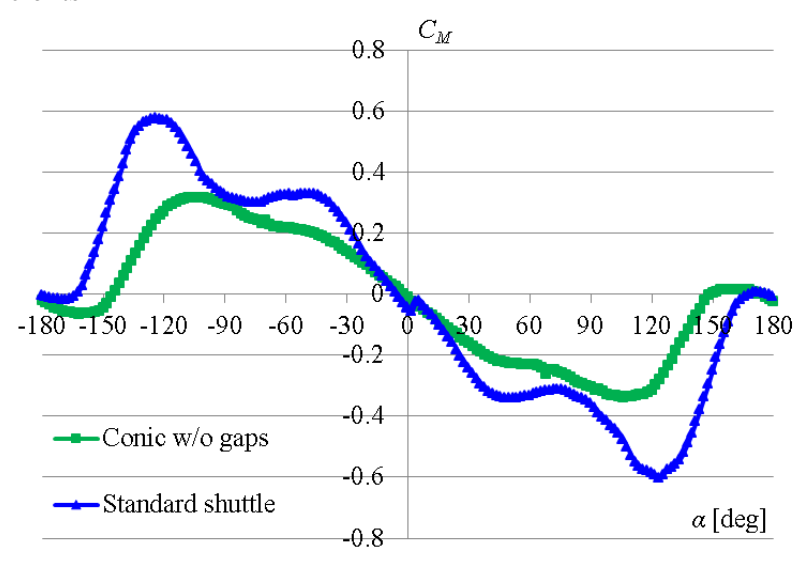

(c) Pitching moment coefficients

Fig. 3 Aerodynamic coefficients of a standard shuttlecock and a conic without gaps as a function of the angle of attack at $R e$ $=1.3 \times 10^{5}$. The differential coefficient of the pitching moment around $\alpha=0$ for a standard shuttlecock becomes larger that for a conic, and a standard shuttlecock has the aerodynamically stable feature for the flip movement (turnover stability). 
きい。こうした隙間部の有無により抗力が変化する理由は，既報で詳細に述べてある(長谷川他，2013)。隙間無 し円錐シャトルでは $0^{\circ}$ から迎角が増加するに従い抗力も増加する. それに対して, 通常シャトルは迎角が $20^{\circ}$ 付 近まで変化しても $C_{D}$ はほとんど変化しない，通常シャトルの場合，シャトル上流からの流れは，シャトル外側 （コルク部やスカート部外側）に沿う流れと，隙間部からシャトル内部を通過する流れの二つある. 迎角が $20^{\circ}$ までの範囲では，シャトル内部を通る流れはスカート内側面に流れを遮られることなく通過する．その結果， $C_{D}$ はほとんど変化しない，一方，迎角が $20^{\circ}$ を超えると隙間部から入り込んだ流れはシャトル内側面を流れ方向に

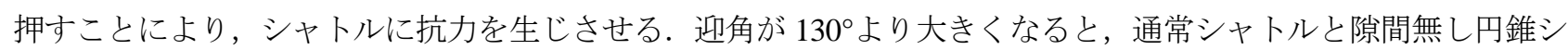
ヤトルの $C_{D}$ は逆転する. 通常シャトルの $C_{D}$ は減少する一方, 隙間無し円錐シャトルでは, 迎角 $180^{\circ}$ に向けて増 え続ける。これは隙間無し円錐シャトルの場合, 大迎角ではスカート部の裾からシャトル内部に入り込んだ流れ がスカート部内側，コルク部を流れ方向に押すことにより抗力が生じる. しかし，通常シャトルの場合，大迎角 ではスカート裾から内部に入り込んだ流れは，隙間部から後流へ流れ出る.この隙間部から出ていく流れにより 実質の投影面積が減少するために， $C_{D}$ は減少する.

図 3(c)にピッチングモーメント係数曲線を示す，そこでは通常シャトル，隙間無し円錐シャトル共に，迎角 $0^{\circ}$ 周りの傾き（微係数）は右肩下がりを示寸.これはシャトルの迎角が大きくなるに従い, 復元モーメントがシャ トルにより大きく作用してゆくことを示している．また， $0^{\circ}$ 付近の $C_{M}$ の微係数は通常シャトルの方が隙間無し 円錐シャトルよりも傾きは大きい。これにより通常シャトルの方が隙間無し円錐シャトルより静安定の高い飛翔 体であることがわかる(加藤他，1982).つまり，隙間の存在により，シャトルはより安定に飛翔することになる.

一方, 迎角が $180^{\circ}$ を超えるあたりでは， $C_{M}$ 值は大略（180を超える領域は-180から $0^{\circ}$ の方に向かって変化して いく）右上がりでゼロを横切る.つまり, 縦回転は不安定となり, これによりシャトルは容易にくるりと（反転 して）進行方向に向きを変え, 最終的に $\alpha=0^{\circ}$ を向く.

\section{$3 \cdot 2$ 急激迎角変化時のシャトル(縦回転) 挙動}

シャトルの流体力特性は迎角によって，また隙間の有無により大きく変化する．そこで形状の違い，および隙 間部の有無がシャトルの縦回転挙動に及ぼす影響を調べた. 実験条件は $R e=4.4 \times 10^{4}(10 \mathrm{~m} / \mathrm{s}), R e=1.3 \times 10^{5}(30 \mathrm{~m} / \mathrm{s})$, 5 回平均の結果をプロットした. 測定結果のばらつきは 7\%以下である. シャトルは大迎角 $\left(\alpha=150^{\circ}\right)$ の場合, 縦 回転安定挙動が損なわれ $180^{\circ}$ で静止してしまう。つまり $180^{\circ}$ は，不安定平衡位置である．そのため，シャトル初 期角度は回転が安定に始まる角度として $\alpha=145^{\circ}$ とした. 縦回転の後, やがてシャトル姿勢は迎角 $0^{\circ}$ に向かって収 斂していく. 安定に至る迎角の定義は縦回転後 \pm 1 ○上変動が見られなくなった時点とし, 具体的には通常シャ トルで約- $7^{\circ}$, 円錐シャトルで約 $0^{\circ}$ であった。綐回転挙動中のシャトルの迎角は高速度カメラを用いて撮影した 画像から求めた．撮影速度は 2000fps，解像度は $512 \times 512$ pixel とした。

図 4 に通常シャトルおよび隙間無し円錐シャトルの縦回転挙動を示寸，横軸は経過時間，縦軸は迎角で，迎角 の符号が変化することはオーバーシュートすることを表す. シャトルは反時計回りに回転し始め, オーバーシュ ートを繰り返したのち安定する. シャトルが初期角度から回転し始め, オーバーシュートを経て迎角 0 付近で安 定するまでに要した時間を $T$ とする．ここで通常シャトルと隙間無し円錐シャトルの安定性の比較を行う．安定 度 $C_{S t b}$ は通常シャトルが, 回転開始後に迎角 $0^{\circ}$ で姿勢变化を起こさず安定になるまでの時間 $T_{\text {std }}$ を基準に $C_{S t b}=T /$ $T_{\text {std }}$ と定義した.つまり，この值が 1 を超えれば隙間無し円錐シャトルに比べ，通常シャトルの方が縦回転後に姿 勢が安定するまでの時間が短いということになる. 異なる $R e$ での縦回転挙動を調べた．その結果， $R e=1.3 \times 10^{5}$ の場合は $C_{S t b}=1.6, R e=4.4 \times 10^{4}$ では $C_{S t b}=1.2$ となった. これは通常シャトルの方が短い時間で安定になるという傾 向を示す．また，各シャトルは風速が大きくなるに従い，安定に至る時間は短くなった，この安定に至るまでの 時間の減少割合は通常シャトルのほうがより顕著となった.これは, 以下の二つの効果が相俟っての結果である.

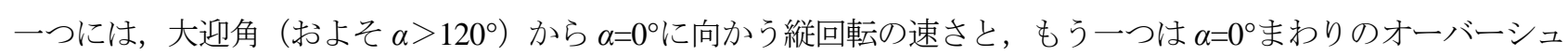
一トが落ち着く時間の短さとである. 前者については, $\alpha=180^{\circ}$ まりでの $C_{M}$ 值のゼロクロス前後における右上 がりの勾配が大きい，つまり不安定性が強いことに起因寸る．このことは，図 3(c)における $\alpha=180^{\circ}$ を超える角度 における $C_{M}$ 值は，-180年ら逆に $0^{\circ}$ 向からデータ曲線につながるとみればよい. 後者については, 前述のとお り， $\alpha=0^{\circ} ま わ り の$ 安定性の強さによる. また, シャトルがオーバーシュートする際のオーバーシュート角の大き さについて通常シャトルと隙間無し円錐シャトルの比較を行った． $R e=4.4 \times 10^{4}$ の場合，隙間無し円錐シャトルは 


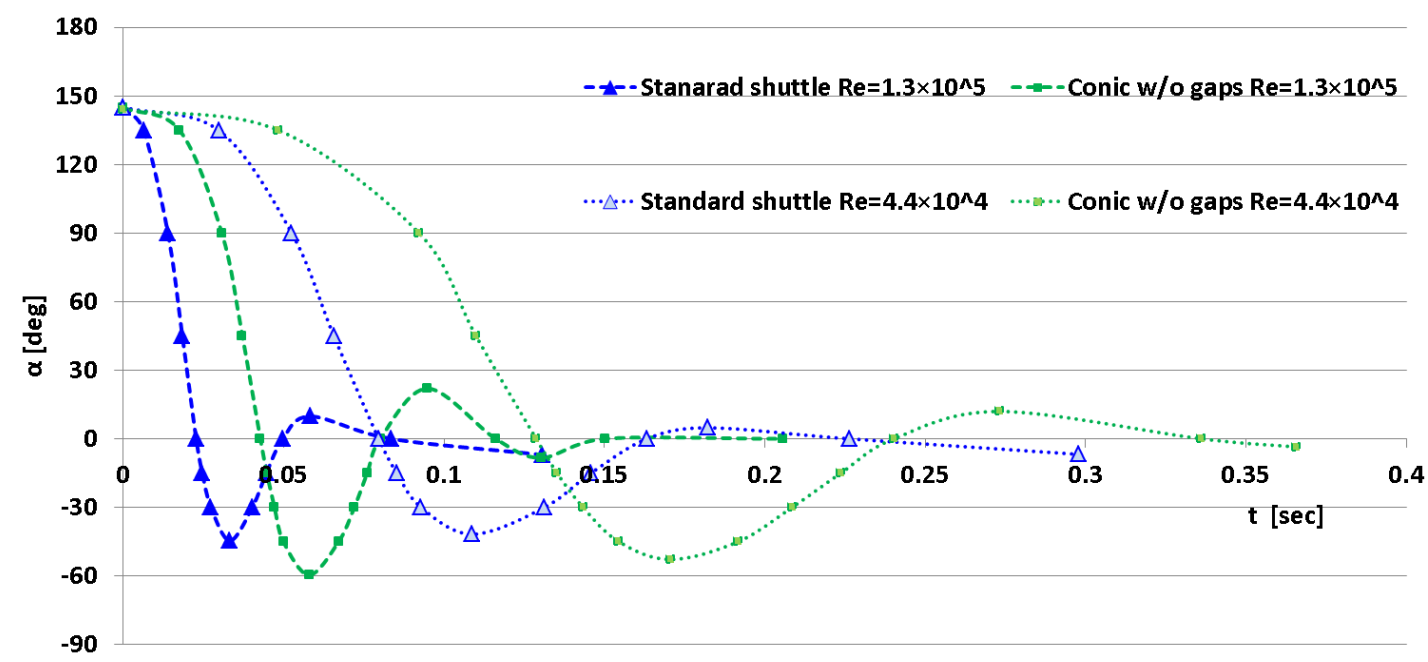

Fig. 4 Time evolution of the angle of attack for each test model during the flip movement. The initial angular velocity for a standard shuttlecock is larger than that for a conic, and the flipping time needed for $\alpha$ to vary from $145^{\circ}$ to $0^{\circ}$ becomes shorter as the Reynolds number increases. The overshoot angle and the stabilizing time become small for a standard shuttlecock. Therefore, a standard shuttlecock has the high turnover stability.

通常シャトルよりも 1.3 倍大きいオーバーシュート角となり, $R e=1.3 \times 10^{5}$ の場合も同様に 1.3 倍大きくなった. こ の結果から通常シャトルは隙間無し円錐シャトルに比ベオーバーシュートしにくい. また，迎角 $0^{\circ} に$ 向かって 徐々に振幅角が小さくなる収束状況から, 通常シャトルの方が安定性の高い飛翔体と言える. 3.1 の後半で述べた 結論がここでも效いてきているのである，通常シャトルが大きな安定性を有する理由は次の 3.3 節にて流れ場か ら詳しく考察する.

\section{$3 \cdot 3$ 縦回転時のシャトル周りの流れ}

通常シャトルと隙間無し円錐シャトルの形状の違いが縦回転挙動に及ぼす影響を調べる為に，流れ場の可視化 をスモークワイヤ法により実施した．図 5 に各シャトルの縦回転時における X-Z 断面の流れ場の可視化結果を示 す. シャトルは反時計回りに自由回転し $\alpha=0^{\circ}$ を通過後，オーバーシュートし， $\alpha=0^{\circ}$ 近傍に安定する. 前述したよ うに通常シャトルは隙間無し円錐シャトルよりも安定になるまでの時間が短い. 加えて，オーバーシュート角は 風速に由らず，通常シャトルよりも隙間無し円錐シャトルのほうが大きい值となる（図 4)。通常シャトルにおい て，隙間を通った流れがスカート部から後流へ流れ出ている（図 5(a)矢印）。一方，隙間無し円錐シャトルでは， コルク部ではく離した流れは,スカート部で再付着寸ることなく下流へ流れる(図 5(b)。印).また，オーバーシュー 卜後, 通常シャトルでは $0^{\circ}$ 一戻る際にスカート部後方に大きな渦が存在している (図 5(a)。印)。この大きなスケ ールの渦の存在は，隙間無し円錐シャトルが 0 に戻る際には確認できない．隙間無し円錐シャトルでは，小さい スケールの渦が連続的に下流側に存在している.こうしたシャトル縦回転時（反時計回り）の流れ場のイメージ を模式的に図 6 に示寸.迎角のマイナスは, シャトルが 0 をを超えてオーバーシュートしていることを示している. オーバーシュート中，隙間無し円錐シャトルではシャトルスカート後方に反時計回りの渦（図 6(b-ii)）が存在し ている. それに対して，通常シャトルでは，スカート後方に渦は確認できない. スカート部付け根の隙間を通っ た流れが後方に流れ出ることで，渦の生成が抑制されている（図 6(a-ii)）。この隙間無し円錐シャトルにおけるス カート後方の渦は，シャトルまわりに時計回りの循環を生む. その結果，シャトルにはオーバーシュート角を大 きくする方向の力が働くことになる．こうして，通常シャトルと比べ， 円錐シャトルではオーバーシュート角が 大きくなる. また，オーバーシュート後のシャトルが $\alpha=0^{\circ}$ へ戻る際の流れ場では（図 6(a-iii)，通常シャトルで は大きな時計回りの渦が存在する. この渦がシャトル周りの反時計回りの循環を強め, $\alpha=0^{\circ}$ に戻る力を大きくし ている.こうして，通常シャトルでは隙間があることで，オーバーシュート角が抑えられ，オーバーシュート後 に $0^{\circ}$ の姿勢に戻りや寸くなる. 


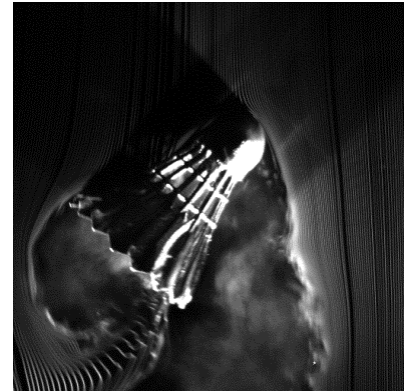

(i) $45 \mathrm{deg}$

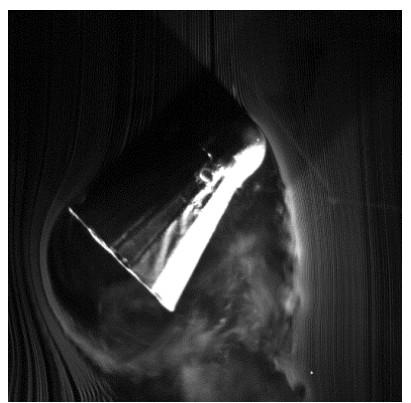

(i) $45 \mathrm{deg}$

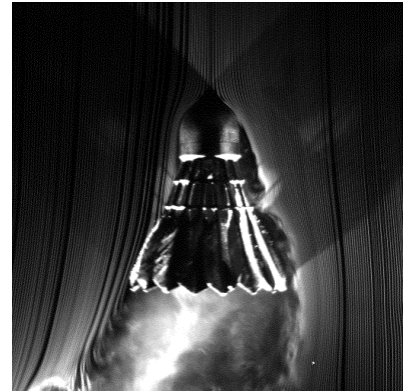

(ii) 0 deg

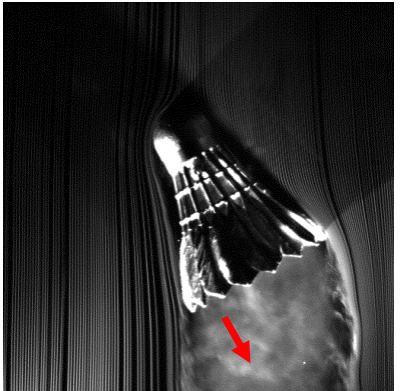

(iii) -30 deg

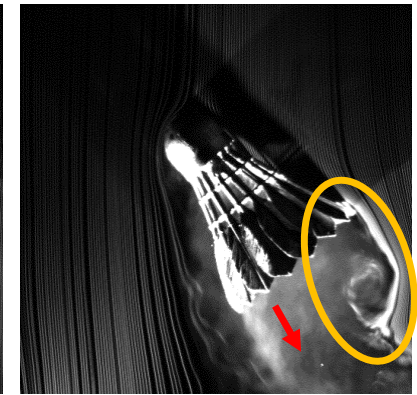

(iv) $-44 \mathrm{deg}$

(a) Standard

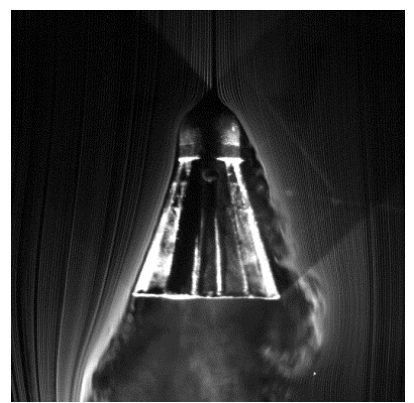

(ii) 0 deg

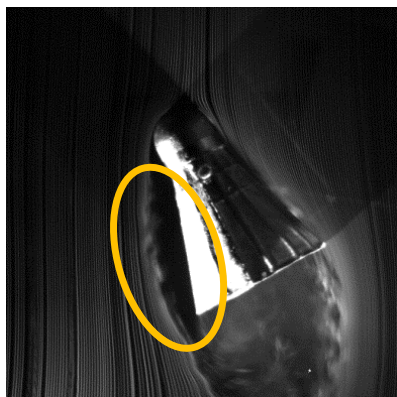

(iii) $-30 \mathrm{deg}$

(b) Conic w/o gaps

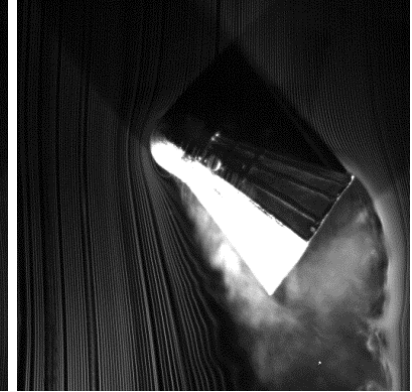

(iv) $-56 \mathrm{deg}$

Fig. 5 The snapshot of the smoke-wire flow visualization during the flip movement after impulsive start from $\alpha=145^{\circ}$ at $R e=$ $4.4 \times 10^{4}$. For a standard shuttlecock, the wake flow is affected by the flow through the gaps into the shuttlecock skirt, and the vortical flow in the wake of a shuttlecock is strongly related to the overshoot behavior for the turnover stability.

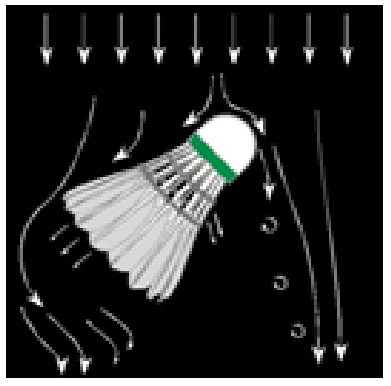

(i) $45 \mathrm{deg}$

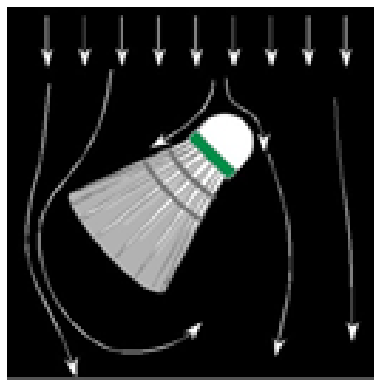

(i) $45 \mathrm{deg}$

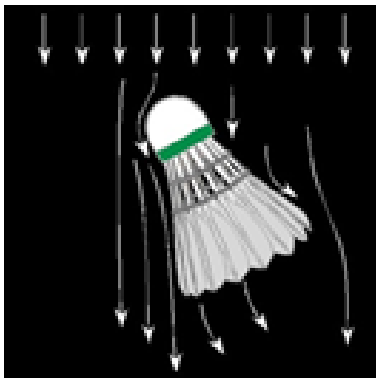

(ii) $-30 \mathrm{deg}$

(a) Standard

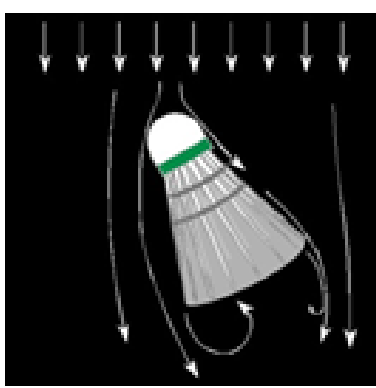

(ii) $-30 \mathrm{deg}$

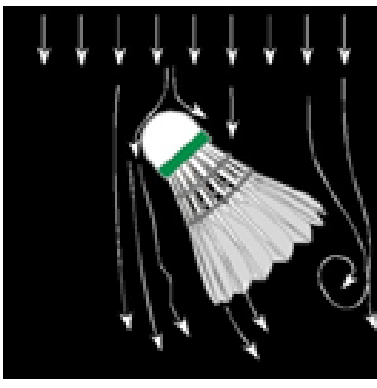

(iii) $-44 \mathrm{deg}$

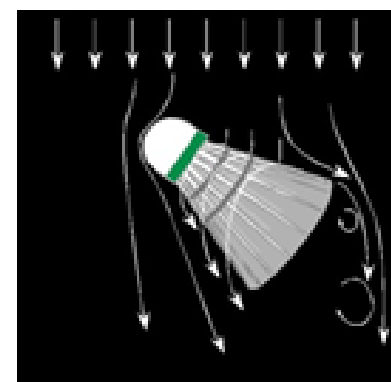

(iii) $-44 \mathrm{deg}$

(b) Conic w/o gaps

Fig. 6 The cartoon depicting of the shuttlecock behavior and flow field around the shuttlecock during flip movement. For a standard shuttlecock, the flow through the gaps suppresses the vortex generation in the wake ((a- ii)), and the overshoot angle becomes smaller in comparison to the conic case. On the contrary, a counterclockwise vortex exists in the wake for a conic (b- ii), and the overshoot angle increases because of the enhancement of the clockwise circulation around the conic. 


\section{4. 結論}

本実験ではシャトルの縦回転時の空力安定性を調べるために，構造の異なるシャトルを用いて，通常シャトル との空力係数および縦回転時の流れ場の違いを調べた．結果は以下のとおりである.

（1）各迎角での揚力変動, 抗力変動において, シャトルの隙間あり, なしで傾向に違いが生じる. 特に迎角 $0^{\circ}$ 回りの $C_{D}$ において通常シャトルは迎角が $\pm 20^{\circ}$ の範囲において大きな変化は見られず，隙間無しシャト ルよりも大きな值となった. ピッチングモーメント係数では迎角 $0^{\circ}$ まわりの $C_{M}$ の微係数は通常シャト ルの方が大きい.

（2）シャトルの縦回転挙動について，隙間無し円錐シャトルよりも通常シャトルの方が，オーバーシュートが 少なく安定に至るまでの時間が短い。このことから通常シャトルの安定性の方が高い.

（3）通常シャトルと隙間なし円錐シャトルでは, オーバーシュートの際にシャトル後端から発生する渦の挙動 に違いが生じる.こうした渦の違いでシャトル周りの循環の大きさに違いが生じ，オーバーシュートを抑 制するように作用する通常シャトルで, 安定性が高い結果となった.

（4）シャトルにおける隙間の存在は, シャトルの空力安定性を高め, シャトルの反転挙動（縦回転）時にシャ トルが短い時間で安定な姿勢で飛翔していくことを可能にする.

\section{謝 辞}

本研究は東北大学流体科学研究所における公募共同研究による. 可視化データ取得に協力頂いた宇都宮大学流 体工学研究室の沖大善氏に感謝の意を表します.

\section{文献}

Alam, F., Theppadungporn, C., Chowdhury, H. and Subic, A., Aerodynamic of badminton shuttlecock, The Impact of Technology on Sport, Vol.3 (2009), pp.239-243.

Alam, F., Chowdhury, H., Theppadungporn, C. and Subic, A., Measurements of aerodynamic properties of badminton Shuttlecocks, Procedia Engineering, Vol.2 (2010), pp.2487-2492.

Cohen, C. Texier, B. D. Quere, D. and Clanet, C., The physics of badminton, New Journal of Physics, Vol.17 (2015), 063001.

Cooke, A., Computer simulation of shuttlecock trajectories, Sports Engineering, Vol.5 (2002), pp.93-105.

Cooke, A., Shuttlecock aerodynamics, Sports Engineering, Vol.2 (1999), pp.85-96.

長谷川裕晃, 和田謙治, 村上正秀, 大林茂, バドミントンシャトルコックの有する高い減速メカニズム, ながれ, Vol.32 (2013), pp.153-162.

加藤寛一郎, 大屋昭男, 柄沢研治, 航空機力学入門 (1982), 東京大学出版会.

小浜泰昭, 小林陵二, 伊藤英覚, 小型低乱風洞の性能測定結果について, 東北大学高速力学研究所報告, Vol.48, No.422 (1982), pp.119-142.

Lin, C. S.H. Chua, C. K. and Yeo, J. H., Turnover stability of shuttlecock -Transient angular response and impact deformation of feather and synthetic shuttlecocks, Procedia Engineering,Vol.60 (2013), pp.106-111.

大川恭平, 田口智清, 宮峷武, 杉浦裕樹, 矢の空力特性に対する細長比の影響, ながれ, Vol.32 (2013), pp.449-456.

鈴木一史, 桝井和典, 向山圭太, 宮峷武, 澤田秀夫, 矢の空力特性-境界層遷移に対寸る先端形状の影響-, なが れ,Vol.29 (2010), pp.287-296.

湯海鵬, 阿江通良, バドミントンのスマッシュ動作の三次元動作解析 - 腕とラケットの速度を中心に - , バイオ メカニズム学会誌, Vol.18, No.3 (1994), pp.164-172.

YONEX., BADMINTON NEWS, available from < http://www.yonex.co.jp/badminton/news/2016/05/1605121500.html >, (参照日 2017 年 10 月 30 日).

\section{References}

Alam, F., Theppadungporn, C., Chowdhury, H. and Subic, A., Aerodynamic of badminton shuttlecock, The Impact of Technology on Sport, Vol.3 (2009), pp.239-243. 
Alam, F., Chowdhury, H., Theppadungporn, C. and Subic, A., Measurements of aerodynamic properties of badminton Shuttlecocks, Procedia Engineering, Vol.2 (2010), pp.2487-2492.

Cohen, C., Texier, B. D., Quere, D. and Clanet, C., The physics of badminton, New Journal of Physics, Vol.17 (2015), 063001.

Cooke, A., Computer simulation of shuttlecock trajectories, Sports Engineering, Vol.5 (2002), pp.93-105.

Cooke, A., Shuttlecock aerodynamics, Sports Engineering, Vol.2 (1999), pp.85-96.

Hasegawa, H., Wada, K., Murakami, M. and Obayashi, S., High aerodynamic drag of a badminton shuttlecock, Transactions of The Japan Society of fluid Mechanics, Vol.32 (2013), pp.153-162 (in Japanese).

Kato, K., Ooya, A. and Karasawa, K., Introduction to aircraft dynamics (1982), The University of Tokyo publication society (in Japanese).

Kohama, Y., Kobayashi, R. and Ito, E., Performance measurement results for low-turbulence heat-transfer wind tunnel, Institute of High Speed Mechanics, Tohoku University,Vol.48, No.422 (1982), pp.119-142 (in Japanese).

Lin, C. S. H., Chua, C. K. and Yeo, J. H., Turnover stability of shuttlecock -Transient angular response and impact deformation of feather and synthetic shuttlecocks, Procedia Engineering, Vol.60 (2013), pp.106-111.

Okawa, K., Taguchi, S., Miyazaki, T. and Sugiura, H., Effect of fineness ratio on the aerodynamic properties of an arrow, A reprint from symposium proceedings, The Japan Society of Fluid Mechanics, Vol.32 (2013), pp.449-456 (in Japanese).

Suzuki, K., Masui, K., Mukaiyama, K., Miyazaki, T. and Sawada, H., Aerodynamic properties of an arrow -Influence of point-shape on the boundary layer transition-, Transactions of The Japan Society of fluid Mechanics, Vol.29 (2010), pp.287-296 (in Japanese).

Tou, K. and Ae, M., Three-dimensional motion analysis for forehand smash in badminton - Mainly on velocity of hand and racket head - , Academic Journal of Society of Biomechanisms Japan, Vol.18, No.3 (1994), pp.164-172 (in Japanese).

YONEX., BADMINTON NEWS, available from < http://www.yonex.co.jp/badminton/news/2016/05/1605121500.html > (accessed on 30 October, 2017), (in Japanese). 